\title{
Phenotypic and genotypic population differentiation in the bivalve mollusc Arctica islandica: results from RAPD analysis
}

\author{
Sebastian P. Holmes*, Rob Witbaard, Jaap van der Meer \\ Nederlands Instituut voor Onderzoek der Zee (NIOZ), Postbus 59, 1790 AB, Den Burg, Texel, The Netherlands
}

\begin{abstract}
The bivalve mollusc Arctica islandica is an important commercial species with a presumed panmictic dispersal strategy, and is widely distributed throughout much of the soft sediment benthos of the North Atlantic continental shelf. Previous studies have shown that there can be gross morphological differences between populations, which has led to the suggestion that this may be reflected in genotype. So far, only one study has examined the population genetics of this species, revealing, depending upon location, that populations are only genetically distinct at a macroscale $(>1000 \mathrm{~km})$, thereby supporting the assumption of panmixia. Examination of the quantitative morphological traits between 5 different populations (4 North Sea and 1 Canadian) determined that all populations could be readily identified from their unique morphologies (shapes/growth patterns) derived from 2 factors resulting from a principal components analysis. Investigation, using random amplified polymorphic DNA (RAPD) analysis, into the genetics of the populations, to indirectly assess whether the observed phenotypic differences could be related to potential differences in genotype, revealed that all populations were genetically distinct (between populations overall $\mathrm{phi}_{\mathrm{ST}}=0.662$ ) from each other even at a microscale $(<25 \mathrm{~km})\left(\mathrm{phi}_{\mathrm{ST}}=0.719\right)$. However, no correlation between genetic distance, morphological distance and/or geographical distance, whatever metric was applied, could be obtained. It is concluded that although phenotypic differences can be used to distinguish between populations of $A$. islandica, it should not and cannot be used to infer genetic differences in the absence of further studies. What is interesting is that the results from the genetic analysis dispute the presumption that the dispersal patterns of $A$. islandica is in any shape or form panmictic. This has very important consequences for the management of the species. The results are discussed with reference to the possible mechanisms responsible for maintaining a high degree of genetic diversity between the populations that were studied.
\end{abstract}

KEY WORDS: Arctica islandica $\cdot$ Dispersal $\cdot$ Genotypic $\cdot$ Panmixia $\cdot$ Phenotypic $\cdot$ RAPD Resale or republication not permitted without written consent of the publisher

\section{INTRODUCTION}

One of the basic prerequisites for the management of any population, whether for commercial or conservation reasons, is knowledge about its reproductive sources and sinks, i.e. is the population reproductively self-sustaining or dependent on immigration for the replacement of senescing individuals. Correspondingly, the level of genetic exchange, arising from immigration, between populations will influence their long-term stability in the face of natural stochasticity (Crisp 1976, Hansen 1978, Jablonnski 1986, Havenhand
1995). For sessile and/or benthic marine species, this is considered to be determined by their mode of reproduction (aplanic, teleplanic, etc.) and the scale/pattern at which their larvae and/or juveniles can disperse (Crisp 1978, Jackson 1986, Scheltema 1989, see Levin \& Bridges 1995 for review). Because direct observation and measurement of the dispersal potential of a marine organism is, at present, practically impossible (Levin 1990, Palumbi 1995), we have to rely upon indirect methods to asses the degree to which different populations are either divergent (self-sustaining) or comparable (exchange recruits). 
One method is to look at the range and number of phenotypic differences between populations. If one population has a sufficiently different phenotype to another population then it may be that both populations are reproductively separated. However, although phenotypic differentiation can be used to distinguish between populations (see Hateley et al. 1992, Daniels et al. 1998, Schwaninger 1999, Comes \& Abbot 2000, Papadopoulou et al. 2002 for examples), unless the environmental and/or physical conditions are identical for both populations it is equally possible that the observed differences in phenotype are a product of plasticity (i.e. local adaptation to the environment) rather than reflecting anything else (see Swain \& Foote 1999 for discussion). An alternative and more reliable method is to examine the genetic structure of populations. The degree to which different populations are genetically divergent will reflect the balance between the potentially diversifying processes of genetic drift and local selection, i.e. those resulting from inbreeding, against the homogenising effect of gene flow, i.e. those resulting from immigration.

The bivalve mollusc Arctica islandica is widely distributed over the Boreo-Arctic continental shelves of both Eastern North America and Europe (Nicol 1951, Tebble 1966), occurring at depths from 4 to $482 \mathrm{~m}$ (Nicol 1951), although it is more commonly found between 10 and $280 \mathrm{~m}$ and is commercially fished between 25 and 60 m (Merrill \& Ropes 1969, Rowell \& Chaisson 1983, Kennish \& Lutz 1995). It usually occupies a muddy/silty habitat and is able to withstand extreme hypoxia (Theede et al. 1969, Oeschger 1990). Sexes are separate (dioecious) and fertilization is external with spawning generally occurring between June and November, peaking in August, September and October, depending on the geographical location (Loosanoff 1953, Jones 1981, Thorarinsdottir 2000, see also Mann 1982 and Rowell et al. 1990). The period between spawning and settlement is of the order of 32 to 55 d (i.e. actae/teleplanic), depending upon the water temperature (Lutz et al. 1982), with the settled juveniles growing rapidly in their first few years to gain sexual maturity at 10 to $13 \mathrm{yr}$ (Thompson et al. 1980a, Rowell et al. 1990, Thorarinsdottir \& Steingrimsson 2000). Growth thereafter is considerably reduced and reaches the order of 0.1 to $1 \mathrm{~mm} \mathrm{yr}^{-1}$ after $30 \mathrm{yr}$, with animals reaching ages in excess of $90 \mathrm{yr}$ (Thompson et al. 1980b, Forster 1981, Murawski et al. 1982, Kraus et al. 1992, Kennish et al. 1994).

Arctica islandica is an important commercial fisheries species, both directly for human consumption (Ropes 1979, Murawski \& Serchuk 1989, Rowell et al. 1990, Fritz 1991, Kraus et al. 1992, Kennish \& Lutz 1995, Witbaard et al. 1999) and indirectly by supporting demersal fish populations (Arntz 1974, Brey et al.
1990, see also Alderstein \& Welleman 2000). However, despite its commercial importance and its relative vulnerability to exploitation (Kennish et al. 1994, Kennish \& Lutz 1995), there is at present only one study, that of Dahlgren et al. (2000), which has attempted to examine its dispersal capacity. Because of the relative length of its planktonic larval stage, in combination with ocean currents, it has been generally assumed that dispersal of the species can take place over considerable distances (Ropes 1979), i.e. it has panmictic dispersal. Accordingly, Dahlgren et al. (2000), from an analysis of mitochondrial cytochrome $b$ haplotypes, found that there was little genetic distinction among Western Atlantic populations separated by considerable geographical distances (>1000 km). However, such results could be due to a founder effect, in addition to which Dahlgren et al. (2000) did determine that differences existed, in terms of haplotypes, between Western and Eastern Atlantic populations and to some extent at a macro scale (>1000 km) within Eastern Atlantic populations. Correspondingly, Witbaard (1997) has recorded that there can be significant phenotypic variation between populations separated by relatively short geographical distances ( $\geq 100 \mathrm{~km})$, leading him to suggest that such differences may reflect genotypic differences between reproductively isolated populations. Given both the existing results recorded by Dahlgren et al. (2000) for the Eastern Atlantic populations, the relatively low genetic resolution of their methodology, i.e. it is a conservative method (see Hillis et al. 1996 for details), and the results obtained by other authors (Burton \& Fieldman 1982, Palumbi \& Metz 1991, Gardner et al. 1996, Heipel et al. 1998), for other actae/teleplanic marine species, it is entirely possible that the phenotypic differences recorded by Witbaard (1997) are due to genotypic differences rather than plasticity. If so, then the implications of such results are of extreme importance for the management of $A$. islandica populations.

The aims of this paper are: (1) To ascertain whether there are phenotypic differences between geographically distinct populations of Arctica islandica and identify the principal discerning characteristics; and (2) to determine, using a fine scale methodology (i.e. RAPD's), if such phenotypic differences can be reflected in genotypic differences between populations, and hence assess their realised dispersal.

\section{MATERIALS AND METHODS}

Arctica islandica $(\geq 30$ individuals covering a broad size range) from 4 geographically distinct populations (Oyster Ground, Fladen Ground, Outer Gullmarsfjord, Inner Gullmarsfjord) were collected using trawls and 
Table 1. Geographical locations of Arctica islandica populations. The number in parentheses indicates additional dead shells used for the morphometric analysis

\begin{tabular}{|c|c|c|c|c|c|}
\hline Collection site & Latitude ${ }^{\circ} \mathrm{N}$ & Longitude & Year of collection & Site code & $\begin{array}{c}\text { No. of specimens } \\
\text { collected for genetic } \\
\text { analysis }\end{array}$ \\
\hline Sweden, Outer Gullmarsfjord & $58: 15$ & $11: 24^{\circ} \mathrm{E}$ & 2000 & OGF & 46 \\
\hline Sweden, Inner Gullmarsfjord & $58: 26$ & $11: 36^{\circ} \mathrm{E}$ & 2000 & IGF & $40(6)$ \\
\hline Fladen Ground (Scotland) & $58: 43$ & $00: 19^{\circ} \mathrm{E}$ & 1999 & $\mathrm{~F}$ & 30 \\
\hline Oyster Ground (Holland) & $54: 20$ & $05: 18^{\circ} \mathrm{E}$ & 1998 & $\mathrm{O}$ & 48 \\
\hline Canada (Nova Scotia) & $43: 39$ & $65: 05^{\circ} \mathrm{W}$ & 1991 & $\mathrm{C}$ & 30 \\
\hline
\end{tabular}

dredges during a series of cruises in the North Sea in 1998, 1999 and 2000. A fifth 'out-group' population (30 individuals) from Nova Scotia, Canada was collected in 1991 (Table 1). Once collected, all specimens were immediately frozen $\left(-20^{\circ} \mathrm{C}\right)$ and stored at $-20^{\circ} \mathrm{C}$ for future processing.

Quantitative trait analysis. The following 10 morphological measurements were made on the shells of all populations sampled, in addition to a further 6 dead shells that had been collected for the Sweden, Inner Gullmarsfjord population: shell height $\left(\mathrm{H}\right.$ to $\left.\mathrm{H}^{1}\right)$, longest point; shell length ( $\mathrm{L}$ to $\mathrm{L}^{1}$ ), longest point; shell width ( $\mathrm{W}$ to $\left.\mathrm{W}^{1}\right)$, thickest section; abductor muscle scar width ( $\mathrm{S}$ to $\mathrm{S}^{1}$ ), measured from the exact centre of each scar; shell thickness (ST to $\mathrm{ST}^{1}$ ), measured on the outside edge only, thickest point; width of the internal mantel edge (MT to $\mathrm{MT}^{1}$ ), widest continuous section; height asymmetry $\left(\mathrm{HA} \text { to } \mathrm{HA}^{1}\right)^{1}$, the longest measurement from the midline, defined by the centre of the 2 abductor muscle scars, to the outside lip of the valve; length asymmetry (LA to $\mathrm{LA}^{1}$ ), defined by the widest section of the valve, to the left, from the line defined by the central cardinal tooth; hinge thickness (HT to $\mathrm{HT}^{1}$ ), defined by the greatest distance between the umbo and the inner edge of the hinge; cardinal teeth dis- tance ( $\mathrm{TH}$ to $\mathrm{TH}^{1}$ ), determined by the distance between the central cardinal tooth and the endpoint of the first cardinal tooth, i.e. that to the left-hand side of the cardinal tooth (see Fig. 1). All measurements, other than those for the whole shell, were made on the left valve of each animal. These measurements were standardised, by dividing all variables by the measurements of shell width, to remove size as a factor (Krzanowski 1993).

Principal component analysis (PCA) was then performed on the derived morphological correlation matrix and the relevant factors, which had a significant contribution towards the overall variance of the model, extracted. To determine if individuals were 'correctly' allocated to their population, as determined by the factors from the PCA analysis, a discriminant analysis was performed on the PCA factor scores. In addition, a dendrogram, based on the average linkage between clusters determined from their Euclidean distances, was derived using hierarchical cluster analysis of the distance $(F)$ matrix generated by the discriminant analysis. Comparison of the significance of the differences between populations, as defined by the factors extracted from the PCA, was then analysed using multivariate general linear modelling followed by matrix
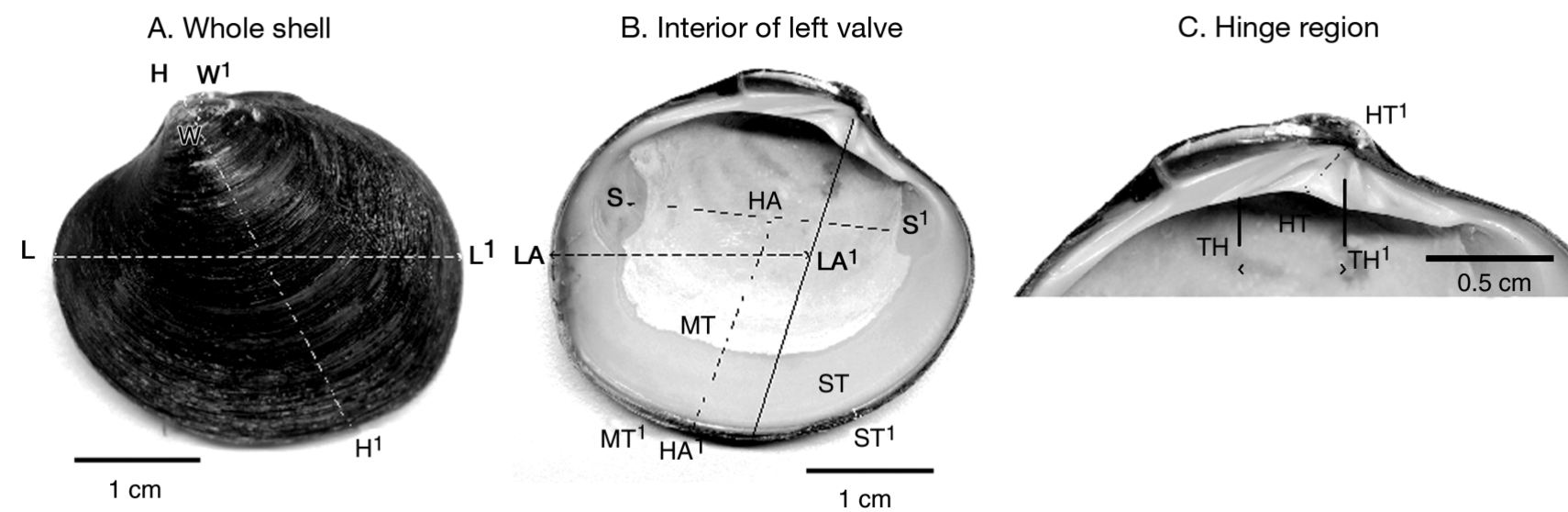

Fig. 1. Morphometric variables measured on the shells 
Table 2. Details of the 6 primers selected for use along with the number of the cycles for the second step of the amplification procedure. \%GC: \% G and C content in primers

\begin{tabular}{|c|c|c|c|c|c|}
\hline Primer label & Sequence $\left(5^{\prime}-3^{\prime}\right)$ & $\% \mathrm{GC}$ & $\begin{array}{l}\text { Optimal number } \\
\text { of second step cycles }\end{array}$ & $\begin{array}{l}\text { Total number of } \\
\text { bands produced }\end{array}$ & $\begin{array}{c}\text { Number of } \\
\text { polymorphic bands }\end{array}$ \\
\hline OPC04 & GGGAATTCGG & 60 & 35 & 26 & 16 \\
\hline UBC212 & GCTGCGTGAC & 70 & 29 & 26 & 16 \\
\hline UBC167 & CCAATTCACG & 50 & 35 & 24 & 16 \\
\hline UBC205 & CGGTTTGGAA & 50 & 35 & 20 & 14 \\
\hline OPG07 & GAACCTGCGG & 70 & 35 & 24 & 17 \\
\hline OPF06 & GGGAATTCGG & 60 & 28 & 23 & 18 \\
\hline
\end{tabular}

comparisons and individual univariate tests for each factor. Mantel tests (Mantel 1967) were then performed to correlate the matrix of morphological differences obtained from the between groups distance $(F)$ matrix, derived from the discriminant analysis, against the geographical distance between the populations. All analyses were made using SYSTAT (Version 10).

Total DNA extractions. In order to speed up processing time, all extractions were made using a commercially available kit (Quantum Prep AquaPure Genomic DNA, Bio-Rad Laboratories) under a modified extraction protocol as follows: (1) approximately $25 \mathrm{mg}$ of frozen posterior adductor muscle was excised from each specimen and placed into a $1.5 \mathrm{ml}$ eppendorf tube, on ice, containing $150 \mu$ l of lysis solution; (2) samples were then homogenised using a micro pestle, $0.75 \mu$ l Proteinase $\mathrm{K}\left(20 \mathrm{mg} \mathrm{ml}^{-1}\right)$ added, and the homogenate incubated in a water bath for $12 \mathrm{~h}$ at $55^{\circ} \mathrm{C}_{i}$ (3) $0.75 \mu \mathrm{l}$ RNase was then added and the homogenate incubated for a further $45 \mathrm{~min}$ at $65^{\circ} \mathrm{C}_{i}(4)$ following this the samples were cooled to room temperature and $100 \mu \mathrm{l}$ protein precipitation solution added; (5) samples were then vortexed for $20 \mathrm{~s}$, centrifuged at $14000 \times g$ for $3 \mathrm{~min}$, and the resulting supernatant poured off into a fresh eppendorf tube containing $150 \mu \mathrm{l} 100 \%$ isopropanol, and mixed by gently inverting 50 times; (6) following this the samples were centrifuged again at $14000 \times g$ for $1 \mathrm{~min}$, the resulting supernatant poured off and the remaining pellet washed in $150 \mu \mathrm{l}$ $70 \%$ ethanol by inverting several times. (7) Step 6 was repeated once more and then the supernatant was poured off and the samples left to be air dried for $1 \mathrm{~h}$; (8) $50 \mu \mathrm{l}$ of DNA hydration buffer was then added to the air-dried pellets and the samples were left to rehydrate overnight at room temperature.

All samples, where appropriate, were stored on ice until the proceeding step. Once hydrated each DNA sample was split $(2 \times 25 \mu \mathrm{l}$ in Eppendorf tubes $)$ and stored at $-20^{\circ} \mathrm{C}$ for future use. The extraction procedure on average yielded $\sim 10 \mu \mathrm{g}$ of DNA. Comparison of the extraction procedure with a standard phenol: chloroform extraction yielded comparable results, although the quality of the DNA extracted with a phenol:chloroform extraction did tend to be better. However, comparison between the PCR products (as outlined below) produced from DNA extracted by either method revealed no difference.

RAPD-PCR protocol. Initially, a random selection of 20 individual DNA samples in sequential dilutions (1:1, $1: 10,1: 100,1: 1000,1: 10,000)$ was run against a series of $25 \times 10 \mathrm{bp}$ primers (Thermo Hybaid). From these initial runs, a DNA dilution of 1:100 was found to produce the best results, both within and between populations, and a subset of 6 primers were selected for further use (Table 2). All amplifications were made in a $25 \mu \mathrm{l}$ volume reaction mix, in a $100 \mu$ reaction tube, made up as follows: $1.5 \mu \mathrm{l}(1.5 \mathrm{U})$ Redtaq DNA polymerase (Sigma); $2.5 \mu l$ Redtaq PCR reaction buffer; $1.0 \mu \mathrm{l}$ DNTP (5 mM); $0.5 \mu l$ primer (1 mM); $0.25 \mu l$ TWEEN-20 (Pharmacia LKB biotechnology AB); $0.5 \mu l$ 1:100 DNA dilution (made with 18 Megohm water (Sigma) and $18.75 \mu 18 \mathrm{Megohm}$ water. It is worth noting that other studies (Patwary et al. 1994, Palumbi 1996) have revealed that the addition of Tween or other similar agents can significantly improve the quantity and quality of products produced. Correspondingly, early trials in optimising our PCR reaction determined that addition of such agents did improve both the quality and quantity of the products produced. The reaction sequence, adopted after initial trials, is outlined in Table 3.

Because of problems with non-specific background products (see Palumbi 1996 for discussion) the number of cycles for the second step of the cycling sequence was individually optimised for each primer (see

Table 3. Reaction sequence after initial trials

\begin{tabular}{|lccccccccccc|}
\hline & \multicolumn{3}{c}{ Step 1 } & \multicolumn{3}{c|}{ Step 2 } & \multicolumn{3}{c|}{ Step 3 } \\
\hline Temp $\left({ }^{\circ} \mathrm{C}\right)$ & 94 & 36 & 72 & $:$ & 94 & 36 & 72 & $: 94$ & 36 & 72 & $: 4$ \\
Duration (s) & 180 & 180 & 180 & $:$ & 30 & 60 & 120 & $: 30$ & 60 & 600 & $: \infty$ \\
No. of cycles & 4 & & $:$ & \multicolumn{3}{c}{$28-35$} & $:$ & & 1 & \\
\end{tabular}


Table 2). Negative controls were run for each batch of reactions and contained no template DNA. All reactions were done in a 96-well Biometria T-gradient thermo-cycler (Biometria) and 2 identical Perkin Elmer 2400, 24-well thermo-cyclers (Perkin Elmer). The heating and cooling rate in the Biometria was reduced to $0.95^{\circ} \mathrm{C} \mathrm{s}^{-1}$ to match that of the Perkin Elmer machines such that replicate trials between all machines produced consistent results. Visualization of the PCR products was by gel electrophoresis on $1.5 \%, 10 \mathrm{~cm}$ path length, Agarose (SEAKEM LE Agarose, BioWitakker Molecular applications) gels. The gels were immersed in $1 \times$ Tris-borate-EDTA (TBE) buffer at $10 \mathrm{~V}$ $\mathrm{cm}^{-1}$ for $90 \mathrm{~min}$. Three lanes of $100 \mathrm{bp}$ molecular ladder (Superladder-mid1, Gensura), which provided intervals every $100 \mathrm{bp}$ from 100 to $3000 \mathrm{bp}$, were included on every gel to allow for fragment comparison. The gels were stained for $30 \mathrm{~min}$ in ethidium bromide $\left(0.001 \mu \mathrm{g} \mathrm{ml}^{-1}\right)$, destained in $1 \times \mathrm{TBE}$ for $10 \mathrm{~min}$ and imaged using a UV imager. The number of bands greater than $100 \mathrm{bp}$ but less than $2000 \mathrm{bp}$ produced for each sample for each primer was then scored for as a presence or absence using the molecular ladder as a reference.

RAPD data analysis. An explicitly genetic analysis of RAPD data, because of its dominant nature, requires that it is either assumed that the populations are in Hardy-Weinberg equilibrium, or that the investigator has some knowledge of the pedigree of the populations (see Lynch \& Milligan 1994, Allegrucci et al. 1995, Stewart \& Excoffier 1996 and Grosberg et al. 1996 for discussion). An alternative approach, and the one adopted here, that negates the necessity of such assumptions is to perform analyses on the RAPD data based solely on the patterns of phenotypic expression (i.e. band absence or presence) (Hillis et al. 1996). Accordingly, the data was analysed in 3 fashions.

Initially, a matrix of Euclidean (unsquared) distances was calculated from the RAPD data $(n=194)$ using SPSS (Version 9.2). The resulting dissimilarity matrix was then subjected to a principal coordinate analysis (PCO) using GenStat (Version 5.2) and the relevant factors extracted. These factors were then analysed using a discriminant cluster analysis to test the reliability with which individuals could be ascribed to their population based on their molecular phenotype, and a dendrogram created using a hierarchical cluster analysis based on the average linkage between clusters determined from their Euclidean distances, on the distance $(F)$ matrix derived from the discriminant analysis. In the second approach, RAPD distance measures were calculated from the molecular phenotype data for all individuals using the DISTANCE option implemented in PAUP* (Version 4.10; Swofford 2002). It is worth nothing that the PAUP* ${ }^{*}$ character distances are similar to those generated by the Euclidean metric of Excoffier et al. (1992). A neighbour joining (NJ) analysis was then performed on the derived distance matrix, using PAUP*, and the robustness of the resulting tree tested by bootstrapping the data, by resampling each indvidual, 1000 times.

In the last approach, examination of both the proportion of variance (in reality covariance, see Excoffier 2000 and Rousett 2000 for details) ascribed within and between populations, and determination of the relevant grouping between populations, if any, that was derived from the PCO analysis, was made using a matrix of squared euclidean distances generated from the molecular phenotype data in SPSS. This matrix was then analysed using analysis of molecular variance (AMOVA; Excoffier et al. 1992) using the ARLEQUIN package (Version 2; Schneider et al. 2000). With RAPD phenotypes treated as haplotypes, ARLEQUIN can compute a haplotypic correlation measure $\left(\mathrm{phi}_{\mathrm{ST}}\right.$; similar to $F_{\mathrm{ST}}$ ) but without considering within individual variation and thus avoiding the dominance problem. That is, the total molecular variance can be partioned due to inter-individual differences within, between and amongst defined populations (Excoffier et al. 1992). In addition, calculation of the pair-wise between-populations phi ST $_{\text {was }}$ corrected for multiple comparisons using the Bonferroni procedure (Sokal \& Rohlf 2000). One thousand random permutations of the data matrix were carried out to assess the significance of the variance components and of the pair-wise variance $\left(\mathrm{phi}_{\mathrm{ST}}\right)$ values for each grouping. In addition, to avoid the need to assume random mating inherent in AMOVA, a genetic distance matrix based on the RAPD data was calculated with unweighted pair-group mean arithmetic average (UPGMA) cluster analysis, and a matrix of the distances (sum of branch lengths) between populations drawn up from the NJ analysis. Finally, a series of mantel tests were performed using both the distance $(F)$ matrix values derived from the discriminant analysis, the phi $i_{\mathrm{ST}}$ and Slatkin's (1985) linearised $F_{\mathrm{ST}}$ values arising from the AMOVA, the matrix of distance from the NJ analysis and the UPGMA cluster analysis data to examine the correlation, if any, between genetic phenotype, geographical and morphological distance. Unless otherwise stated, all analyses were perfomed using SYSTAT.

\section{RESULTS}

\section{Principal component and discriminant analysis}

Principal component analysis of the standardised morphological data revealed that there were 3 main factors accounting for $\sim 78 \%$ of the total variance 
Table 4. Arctica islandica. Factor loadings, eigenvalues and percentages of variance explained for the first 3 factors extracted from the morphological data for the 5 populations

\begin{tabular}{|lrrr|}
\hline Character (code) & \multicolumn{3}{c|}{$\begin{array}{c}\text { Factor } \\
\text { 2nd }\end{array}$} \\
& 1st & 3rd \\
\hline Shell length (L) & 0.944 & 0.030 & -0.087 \\
Shell height (H) & 0.921 & -0.098 & -0.155 \\
Muscle scar width (S) & 0.932 & 0.008 & -0.166 \\
Shell thickness (ST) & -0.431 & -0.707 & 0.289 \\
Length asymmetry (LA) & 0.882 & 0.076 & 0.081 \\
Hinge thickness (HT) & 0.198 & -0.787 & 0.080 \\
Cardinal teeth distance (TH) & 0.666 & -0.457 & -0.127 \\
Height asymmetry (HA) & 0.329 & 0.179 & 0.865 \\
Mantle thickness (MT) & 0.703 & 0.120 & 0.309 \\
Eigenvalues & 4.657 & 1.392 & 1.015 \\
\% of total variance & 51.74 & 15.472 & 11.283 \\
Cumulative\% & 51.74 & 66.94 & 78.22 \\
& & & \\
\hline
\end{tabular}

(Table 4). A complete data set for all populations and all variables is available at www.sebby.co.uk/data.htm. Observation of the loadings for each factor (Table 4) revealed for the first factor that shell length, shell height, abductor muscle scar width, length asymmetry, mantle thickness, and to a lesser extent cardinal teeth distance, were all strongly positively correlated with each other but negatively correlated with shell thickness. For the second factor, hinge thickness and shell thickness were strongly negatively correlated with each other. For the third factor height asymmetry, mantle thickness and shell thickness were reasonably correlated with each other. Because the strength of the correlations for the third factor were considered to be weak, and to aid interpretation, the third factor was discarded in all further analyses and only the first 2 factors were considered. The first 2 factors are considered to be shape/growth variables describing the relationship of one set of shape/growth factors against another. That is, for the first factor (Shape 1) the combined loadings are deemed to describe the positive relationship of shell length, shell height, abductor muscle scar width, length asymmetry, mantle thickness and cardinal teeth distance against each other, but negatively against shell thickness, i.e. effectively as the size of a shell increases in both the vertical and horizontal plane its relative shell thickness decreases. Correspondingly, for the second factor (Shape 2) the loadings describe the negative relationship of hinge thickness against shell thickness, i.e. as the thickness of the hinge increases in the vertical plane (size/growth), the relative thickness of the shell decreases. A vector plot of the loadings for the 2 factors is given in Fig. 2.

Observation of a principal component plot for the first 2 factors reveals that there appear to be differences between the populations according to their morphologies (Fig. 2). In particular, the Oyster Ground, Outer Gullmarsfjord, Fladen Ground and Canadian populations appear to be separated from each other, although there is considerable overlap between

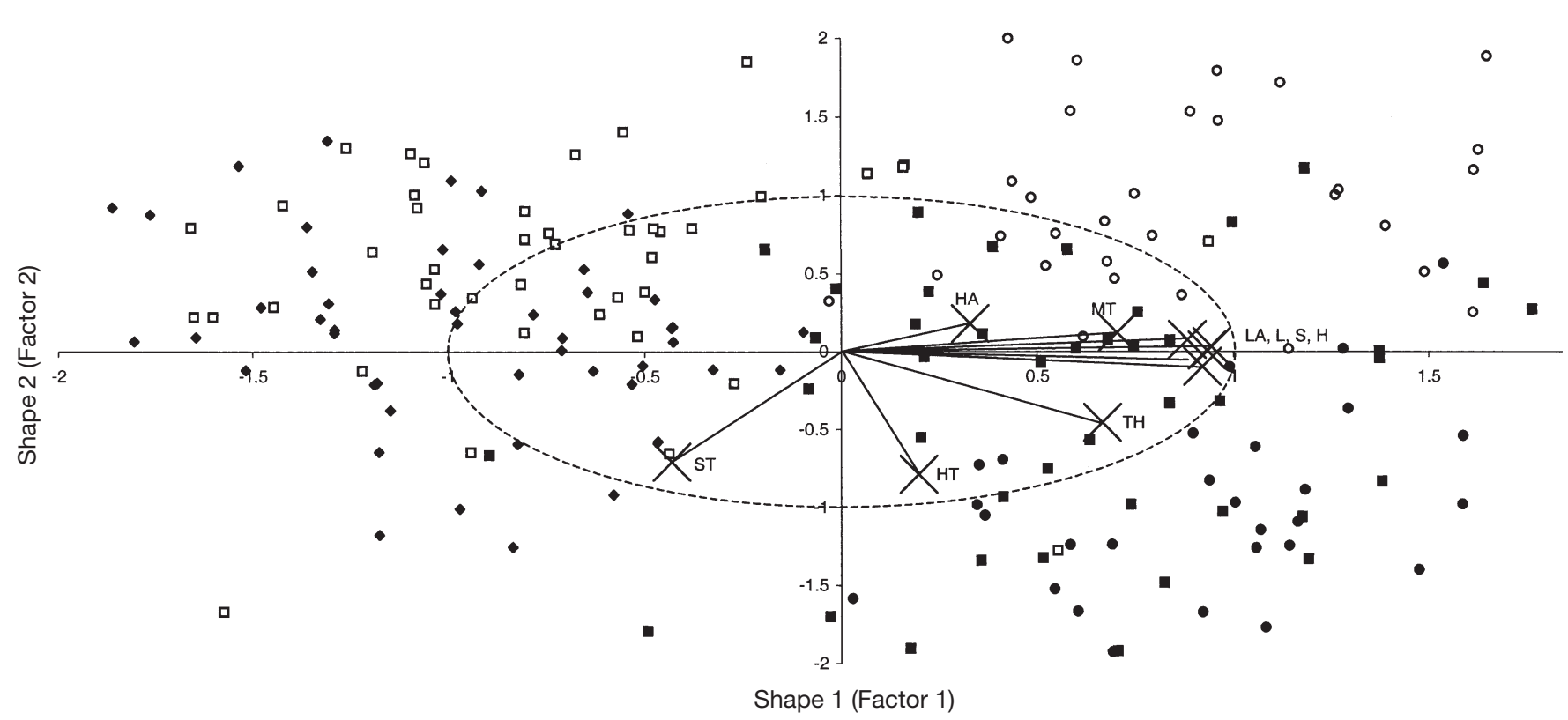

- Oyster Ground (O) — Sweden, Inner Gullmarsfjord (IGF) a Sweden, Outer Gullmarsfjord (OGF) ○ Canada (C) • Fladen Ground (F) XFactor loadings

Fig. 2. Biplot of the principal component analysis and vector plot for the 2 extracted factors (shapes) derived from the 10 morphological variables for the 5 populations 
the Inners Gullmarsfjord population and the Fladen Ground population. Discriminant analysis of the 2 shapes (factors) derived from the PCA determined that all populations could be separated from each other on the basis of the morphologies according to the 2 shape factors. Calculation of the frequency, using a jackknifed classification matrix, with which the populations could be assigned to a population based on their measurements, revealed that overall $70 \%$ of the individuals could be correctly assigned to their respective populations. For the Canadian, Fladen ground, and Oyster Ground populations the accuracy of classification was $\geq 77 \%$, dropping to $72 \%$ for the Outer Gullmarsfjord population and to $43 \%$ for the Inner Gullmarsfjord population (see Fig. 3), i.e. the source of the majority of misclassification, with $\sim 31 \%$ of the samples being assigned to the Fladen Ground and the remaining $26 \%$ between the other populations. Multivariate analysis of the 2 factors determined that division between the populations according to either factor could be made independently. Corresponding univariate analysis, based on pair-wise comparisons, of each factor revealed for the first factor that all populations were significantly different from each other with the exception of the Canadian and Fladen Ground populations. For the second factor, all populations were found to be significantly different from each other.

Hierarchical cluster analysis of the distance $(F)$ matrix, derived from the discriminant analysis, revealed that the populations could be separated into 2 distinct nodes, with the Outer Gullmarsfjord and the Oyster Ground populations forming one node and the Canadian, Inner Gullmarsfjord and Fladen Ground populations forming the second node (Fig. 3). A mantel test performed on the distance $(F)$ matrix derived from the discriminant analysis and the geographical distance of the populations to each other revealed no statistically significant correlation, irrespective of any transformations that were applied.

Examination of individual population morphology by eye determined that we could allocate shells with a reasonable degree of success to their respective population, based solely on their gross shell shape. In general each population exhibited the following gross morphologies. (1) Fladen Ground population: the shells tended to be truncated on both sides with the muscle scars set close to the margin; (2) Canadian population: the shells were very broad across their width with little visible truncation; (3) Oyster Ground population: a broad shell, less so than the Canadian population, with truncation only on the left side; (4) Inner Gullmarsfjord population: very circular shells with no visible truncation; (5) Outer Gullmarsfjord population: almost square shells with considerable truncation.

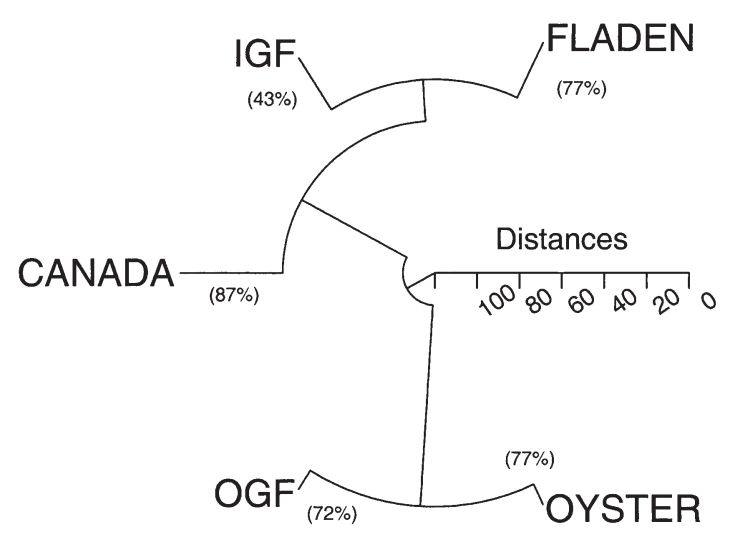

Fig. 3. Dendrogram derived from hierarchical cluster analyses based on the distances generated from the discriminant analysis. The numbers in parentheses are the jackknife estimates, from the discriminant analysis, for the accuracy with which an individual can be assigned to a particular population based on its morphology as determined by the first 2 factors derived from the PCA analysis

\section{RAPD analysis}

In the 194 individuals of the 5 populations studied, the 6 primers that were used amplified a total of 120 different fragments, 23 of which were monomorphic (Table 2). A complete data set of the banding patterns for all populations and primers are available at www.sebby.co.uk/data.htm. In general, all of the primers used showed population specific fragments, although both the frequency and exact differentiation of such fragments varied between primers. Analysis of the data using PCO resulted in the extraction of 3 factors which accounted for $\sim 27, \sim 16$ and $\sim 12 \%$ of the total variance, respectively, before the subsequent factors appeared to asymptote. A plot of the first 3 factors revealed that all populations appeared to be distinct from each other, with the Canadian, Oyster Ground and Fladen Ground populations occupying a similar region of space, i.e. these populations, although different from each other, appeared to share common features (banding patterns) (Fig. 4). Discriminant analysis of the first 3 factors derived from the PCO analysis determined that all populations could readily be separated from each other. Calculation of the frequency, using a jack-knifed classification matrix, with which a particular individual could be ascribed to its relevant populations, revealed that all individuals could be placed within their respective population with $100 \%$ accuracy (Fig. 5). Hierarchical cluster analysis of the distance $(F)$ matrix (Table 5) derived from the discriminant analysis determined, as would be expected from the PCO plot, that the populations could be separated into 3 distinct nodes, the Canadian and Fladen Ground 


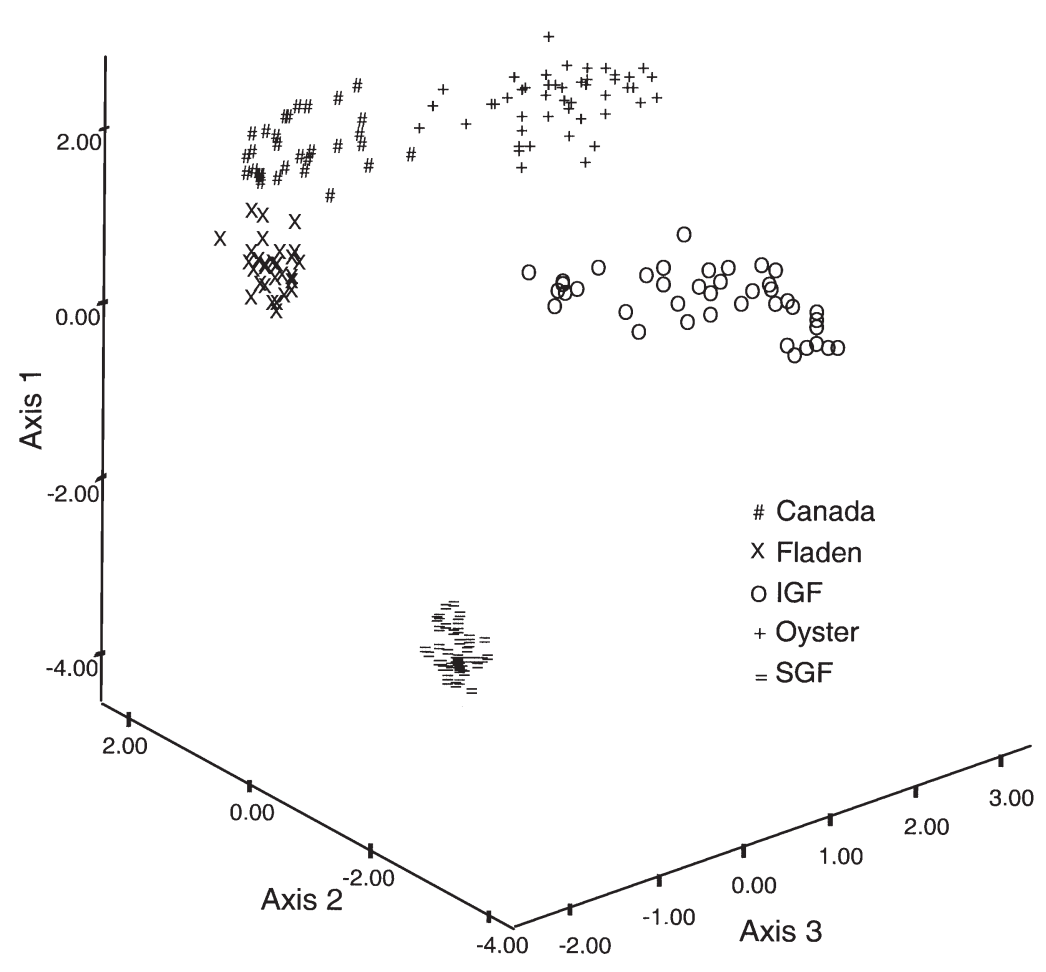

Fig. 4. Plot of the 3 factors extracted from the principal coordinates analysis of the Arctica islandica phenotype RAPD data

(Fig. 6). Bootstrapping, based on resampling each indvidual, of the derived tree revealed, although with slightly less accuracy than the discriminant analysis, that the assignment of a particular individual to a particular population could be made with $\geq 83 \%$ accuracy $(\sim 100 \%$ accuracy for the Outer Gullmarsfjord population, $\sim 94 \%$ accuracy for the Canadian and Inner Gullmarsfjord populations, $93 \%$ for the Fladen Ground population and 83\% for the Oyster Ground population) (Fig. 6). Observation of the branch lengths showed, as for the hierarchical cluster analysis, that the Outer Gullmarsfjord population had the longest branch length connecting it to the Inner Gullmarsfjord population, with the Canadian, Fladen and Oyster Ground populations forming a corresponding sub-cluster.

Analysis of molecular variance based on the precept, as determined from the PCO analysis, that all populations were different from each other revealed that $\sim 66 \%$ of the total variance could be attributed to between population differences and the remaining $34 \%$ to within population differences (Table 6). Any attempts at sub-

populations forming one node linking to a second node for the Oyster Ground population (Fig. 5). Meanwhile, the Outer Gullmarsfjord population formed the third node, linking it to the Inner Gullmarsfjord population and the previous nodes (Fig. 5).

Construction of a neighbour joining tree determined, as for the discriminant analysis, that the individuals from all populations could be separated into respective populations on the basis of their banding patterns

Table 5. Arctica islandica. Matrix of the distances derived from the discriminant analysis and the estimates of the pairwise between population variances ( $\mathrm{phi}_{\mathrm{ST}}$ ) from the AMOVA of the RAPD banding data. IGF: inner Gullmarsfjord, OGF: outer Gullmarsfjord. The numbers above the diagonal are derived from the distance $(F)$ matrix generated by the discriminant analysis and below the analysis from the AMOVA. Significance levels, estimated, for the AMOVA are the probability that a random phi $\mathrm{ST}_{\mathrm{ST}}$ value is greater than an observed value. ${ }^{*} p<0.001$

\begin{tabular}{|lccccr|}
\hline & Canada & Fladen & IGF & OGF & Oyster \\
\hline Canada & & 124.616 & 744.550 & 2900.144 & 586.693 \\
Fladen & $0.636^{*}$ & & 813.688 & 1777.159 & 696.139 \\
IGF & $0.606^{*}$ & $0.610^{*}$ & & 3708.382 & 2109.025 \\
OGF & $0.802^{*}$ & $0.758^{*}$ & $0.719^{*}$ & & 3504.810 \\
Oyster & $0.553^{*}$ & $0.565^{*}$ & $0.560^{*}$ & $0.758^{*}$ & \\
\hline
\end{tabular}
dividing the populations into groups, e.g. combining the Fladen Ground and Canadian population into 1 group, resulted in a decrease in the between populations variance and a corresponding increase in the

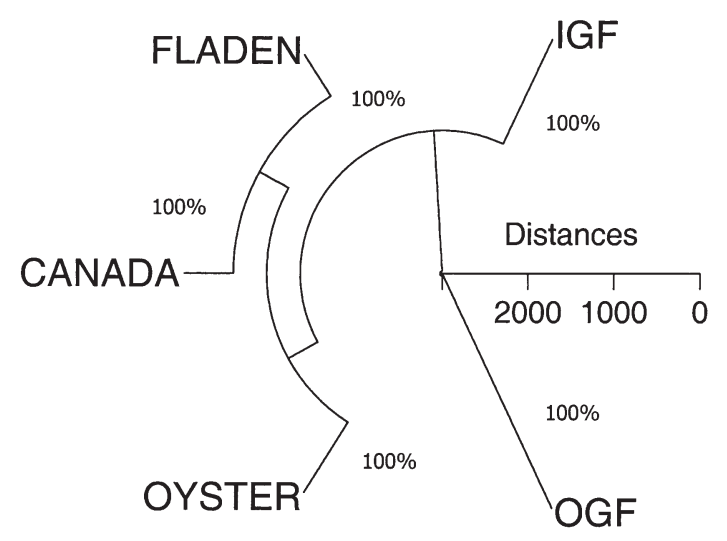

Fig. 5. Dendrogram derived from a hierarchical cluster analysis based on the sum of differences between populations according to their RAPD phenotypes as derived from a discriminant analysis of the first 3 factors derived from a principal coordinate analysis of the RAPD data. The percentages given represent the jackknifed accuracy with which an individual can be assigned to a particular population based on its genetic phenotype as determined by the first 3 factors from the PCO analysis 


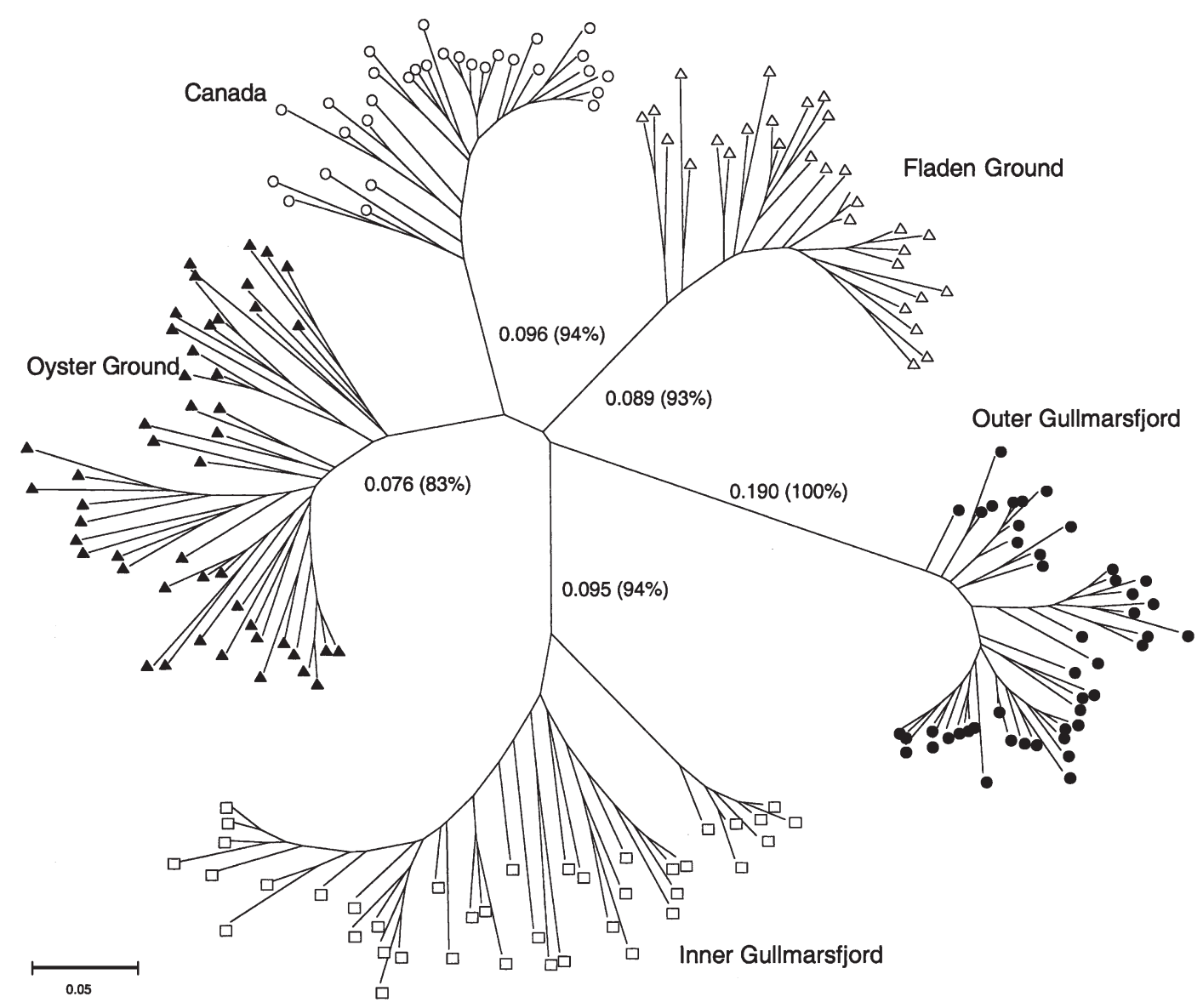

Fig. 6. Unrooted dendrogram calculated using neighbor joining from the RAPD phenotypes of Arctica islandica. The numbers along the main tree branches indicate the branch length (from the center) and the numbers in parentheses represent the bootstrap values, calculated over 1000 replicates, for that particular branch

within populations variance. In effect, the majority of the variance between samples arises from between population differences rather than within. Calculation of the between population pair-wise variances (phisT), after correction for multiple comparisons, revealed that the genetic identity, as determined by the RAPD banding patterns, of all populations was different (Table 5). In addition, both the among (Table 6) and between population (Table 5) phi $\mathrm{ST}_{\mathrm{ST}}$ values were high, indicating a considerable degree of genetic structuring.

Table 6. Arctica islandica. AMOVA table for the RAPD data. ${ }^{*} \mathrm{p}<0.001$

\begin{tabular}{|lrrrrr|}
\hline Source & df & SS & Variance & $\begin{array}{l}\text { \% of } \\
\text { variance }\end{array}$ & phi \\
& & & & & \\
\hline Among populations & 4 & 2197.425 & 14.110 & $66.18^{*}$ & $0.662^{*}$ \\
Within populations & 189 & 1363.044 & 7.212 & 33.82 & \\
Total & 193 & 3560.469 & 21.322 & & \\
\hline
\end{tabular}

Mantel tests performed to examine the correlation, if any, between genetic, morphological and geographical distances/differences between the populations using all of the various indices failed to reveal any discernible relationships, irrespective of the indices and/ or matrix combinations.

\section{DISCUSSION}

Analysis of the quantitative traits (phenotypes) between the populations revealed, in line with the results of Witbaard (1997), that all populations could be separated on the basis of their morphology. However, no relationship between geographical distance and morphological similarity (or dissimilarity) could be obtained. Hence, although individuals can be accurately assigned to a population on the basis of their morphological characteristics, i.e. the 2 derived shape factors, there appears to be no underlying causal relationship between the populations for the possession of 
a particular phenotype, as determined by their degree of geographical separation. It is apparent however, that there are differences in the growth strategies adopted by different populations. For the time being, ignoring the results obtained from the genetic analysis shows that there are 3 possible explanations for the apparent lack of correlation between phenotype and geographical separation.

The first is that the observed morphology for a particular population is plastic in nature. Such an explanation is particularly applicable if we consider the larval dispersal of Arctica islandica to be panmictic. That is, the particular morphology adopted by a population is a reflection of localised adaptation to habitat. For example, Kraus et al. (1992) and Witbaard et al. (1999) have recorded that different populations of A. islandica have different growth rates which have been ascribed to differences in water temperature, food availability, sex ratios and grain size (see Lutz et al. 1982, Witbaard \& Duineveld 1990, Witbaard et al. 1997 1999). A second explanation is that A. islandica sampled from heavily fished populations will show a similar morphology, which has resulted from shell damage (Rumohr \& Krost 1991, Witbaard 1997). However, this explanation cannot be invoked to explain all of the potential differences between populations, especially where fisheries are absent (see Witbaard 1997), i.e. for the populations studied here, the Inner Gullmarsfjord, Fladen Ground and to a lesser extent the Outer Gullmarsfjord populations. The third explanation is that populations may be reproductively isolated from each other, and hence, to some extent, phenotypic differences may reflect genotypic differences.

Analysis of the RAPD PCR genetic data revealed, as for morphological data, that all populations were different. This is in contrast to the results recorded by Dahlgren et al. (2000) for Western Atlantic Arctica islandica populations. Dahlgren et al. (2000) found that A. islandica populations either side of the Atlantic were genetically distinct from each other but relatively homogenous within their own boundaries, although it should be noted that they did find some differences between genetic haplotypes within Eastern Atlantic populations, but only at a very large scale $(>1000 \mathrm{~km})$. The difference between the results recorded here (i.e. over comparatively short distances) and those recorded by Dahlgren et al. (2000) can, in part, be ascribed to the relatively low resolution of the methodology used and acknowledged by Dahlgren et al. (2000) (see Hillis et al. 1996 for discussion).

Examination of genetic relatedness between populations, as determined by genetic phenotype, revealed for both forms of analysis (hierarchial cluster and neighbour joining) that the Fladen Ground, Canadian, Oyster Ground and Inner Gullmarsfjord populations (phi ${ }_{\mathrm{ST}}$ 's of the order 0.55 to 0.64 , pair-wise comparisons) appeared to share a common ancestry in contrast to the Outer Gullmarsfjord population $\left(\mathrm{phi}_{\mathrm{ST}} \mathrm{s} \mathbf{\mathrm { s }}\right.$ > 0.72 , pair-wise comparisons). However, it is equally possible that all populations may derive from the same ancestral stock, but that the Outer Gullmarsfjord population has undergone a recent founder (bottleneck) effect. Any attempts to correlate genetic similarity (or dissimilarity) with geographical distance and/or phenotypic similarity (or dissimilarity) failed to reveal any relationship, whichever metric was applied. In effect, although phenotypic differences can be used to distinguish between populations, and in this study such differences are indicative of a genetic differences between such populations, these phenotypic differences cannot and should not be relied upon to describe probable genetic differences.

Because Arctica islandica is an actae/teleplanic species and therefore should be panmictic in its dispersal (Ropes 1979), it might appear unusual that all of the sampled populations were so genetically distinct, especially given the relative proximity of the 4 North Sea populations. However, as has been mentioned, given that other authors have recorded similar results for other actae/teleplanic species (see Burton \& Fieldman 1982, Palumbi \& Metz 1991, Gardner et al. 1996, Heipel et al. 1998), there are 2 mechanisms that can be invoked to explain why the population genetics of actae/teleplanic species don't appear to follow the panmictic paradigm. The first mechanism is that of reproductive isolation arising from either geographical physical and/or biological constraints, i.e. population isolation in combination with random genetic drift can very rapidly produce considerable genetic heterogeneity. If it is assumed that the longevity of $A$. islandica larvae in the water column is around $60 \mathrm{~d}$ (i.e. the maximal time period as recorded by Lutz et al. 1982), then there should be sufficient time for the larvae, in the absence of predation, to reach Eastern Atlantic coasts from Western Atlantic coasts. However, once predation and/or larval mortality in accordance to the period of exposure is added into the equation, the longer the time the larvae spend in the water column the less likely they are to survive, and hence, it is highly unlikely that any larvae from the Western Atlantic coast ever reach the Eastern Atlantic and vice/versa (see Pechenik 1987 1999, Morgan 1995, Shanks 1995 for review). For example, Dahlgren et al. (2000) have shown that Eastern and Western Atlantic A. islandica populations are genetically distinct, as is the Canadian population in this study, to all other populations. In general, geographical separation, particularly when there are gross climatic differences and distances between regions/sites, will act as the major factor responsible for maintaining distinctive popula- 
tion genotypes (Hartl 1980). It is worth noting, however, that if there is sufficient gene flow between geographically distinct populations, genotypes can 'hop-scotch' (jump) between populations resulting in genetic homogeneity. Hop-scotching is possible for North Eastern Atlantic/North Sea A. islandica populations (Dahlgren et al. 2000) but not for Southern Eastern Atlantic/Southern North Sea A. islandica populations because of the depth of the mid Atlantic ocean.

In addition to geographical constraints, biological and physical constraints such as variations in water temperature (Lutz et al. 1982, Mann \& Wolf 1983), longevity of larval life (Loosanoff 1953, Lutz et al. 1982), the timing of spawning (seasonal isolation) (Thorarinsdottir 2000) and the prior occupation of habitats by juvenile conspecifics (Fritz 1991) can all act to cause/maintain reproductive isolation. In particular, the role of gyres and currents in defining population boundaries has become apparent in the last decade (see Ruzzante et al. 1998 1999, Bucklin et al. 2000, Stepien et al. 2000, Hill et al. 1996, Ruzzante et al. 1999). For example, Svendsen et al. (1991) and Turrell $(1992 a, b)$ have both shown that a semi-permanent, topographically steered cyclonic eddy dominates the central parts of the Fladen Grounds. The presence of such an eddy has led Witbaard (1996 1997) to propose that the population structure of Arctica islandica found within the Fladen grounds results from localised self recruitment arising from the effects of the eddy (see also Wilde et al. 1986, Bailey et al. 1995, Witbaard et al. 1997).

A second mechanism, which can cause genotypic differentiation in the absence of reproductive constraints, is that of the localised supply of external recruits to a population, which are genotypically very different to all other populations. For example, Van Oppen et al. (1995) have shown, from RAPD data, that populations of the benthic algae Phycodrys rubens are genetically distinct between the North Sea and Baltic Sea with both genotypes occurring individually and as a hybrid form in the Skagerrak and Kattegat region (see also Vainola \& Hvilsom 1991, Rohner et al. 1996). From personal observation (R. Witbaard), the phenotype of Arctica islandica within the Baltic Sea is very different to that found elsewhere, in part due to the reduced salinity of the basin, but may be also in part resulting from a different genotype.

For the populations studied, we envisage that reproductive isolation through geographical (Canadian population to all others and to some extent within the North Sea populations) and physical isolation, by virtue of the gyre in the Fladen Ground and to a limited extent biological constraints, are responsible for maintaining the heterogeneity between the populations. In addition, given the proximity of the Outer and
Inner Gullmarsfjord populations to each other (i.e. the population sampled from Farljfjorden is $\sim 20 \mathrm{~km}$ from the fjord entrance), it is probable that the Inner Gullmarsfjord population is some manner extremely isolated from all other populations. For example, water exchange between the fjord and sea is highly restricted because of a sill of $\sim 20 \mathrm{~m}$ depth at the entrance to the fjord resulting in prolonged periods (>3 mo) of stratification and hypoxia (Leppakoski 1968, Josefon \& Widbom 1988, Diaz \& Rosenberg 1995; see also Rosenberg 1990, Nordberg et al. 2000). Because of stratification and hypoxia, any immigrants to the fjord are unlikely to recruit to the existing population, which in turn must self-recruit once stratification has passed and normoxia returned. A further consideration, which, although it has been eluded too, is highly speculative, is that both the Outer and Inner Gullmarsfjord populations may in some part be representative of a hybrid (in terms of genotype) between North Sea and Baltic Arctica islandica. Irrespective of the real causes for the formation and subsequent definition of the different genotypes for the populations of $A$. islandica, what is apparent is that the dispersal potential of $A$. islandica, despite the length of its larval life, is in no way panmictic. The mechanisms, some of which have been outlined above, for preventing global mixing (panmixia) are in our opinion self-evident and in reality reflect common sense. For example, wind dispersed seeds have the potential to be deposited worldwide, however, we no longer expect to find the same plants in different parts of the world given similar habitats. Therefore, the continued acceptance of the concept of panmixia, especially in fisheries, is of great concern given that the dispersal potential of species may not be as great as it seems. For A. islandica, great care must be taken when devising both fishery quotas and conservation measures to ensure the survival of existing stocks/populations. At the very least, a considerable amount of work has to be done to correctly identify the various sources and sinks that a particular population may possess.

In summary, quantitative trait analysis of 5 different Arctica islandica populations revealed that the populations could be distinguished on the basis of their morphologies. Correspondingly, RAPD PCR analysis of the genotypes between populations, determined as for the phenotypic data, that all of the studied populations were genetically distinct to each other. However, although phenotype may be indicative of genotypic differences between populations, it cannot and should not be used to infer a genotypic difference. In contrast to what may be expected, the dispersal potential and/or the level of genetic similarity between populations is much less than that has been previously presumed. The implications of such results of are of 
extreme importance to fisheries in determining how populations should be managed. In addition, it may be that the results of this study are applicable to a wider range of actae/teleplanic species for which the concept of panmixia is considered to be appropriate.

Acknowledgements. We would like to note that this research was in part funded by a NIOZ fellowship held by the first author, and that the collection of specimens in Sweden was made possible by the European Union Access to Research Infrastructure (ARI) Scheme (Grant no: ARI P.2).

\section{LITERATURE CITED}

Adlerstein SA, Welleman HC (2000) Diel variation of stomach contents of North Sea cod (Gadus morhua) during a 24-h fishing survey: an analysis using generalized additive models. Can J Fish Aquat Sci 57:2363-2367

Allegrucci G, Caccone A, Cataudella S, Powell J, Sbordoni V (1995) Acclimatisation of the European sea bass to freshwater: monitoring genetic changes by RAPD polymerase chain reaction to detect DNA polymorphisms. Mar Biol 121:591-599

Arntz WE (1974) A contribution to the feeding ecology of the juvenile cod Gadus morhua (L.) in the western Baltic. Rapp P-V Reun Cons Int Explor 166:13-19

Bailey N, Chapman CJ, Afonso-Dias M, Turrell W (1995) The influence of hydrographic factors on Nephrops distribution and biology. ICES Counc Meet Pap 17:1-13

Brey T, Arntz WE, Pauly D, Rumohr H (1990) Arctica (Cyprina) islandica in Kiel Bay (Western Baltic): growth, production and ecological significance. J Exp Mar Biol Ecol 136: 217-235

Bucklin A, Astthorsson OS, Gislason A, Allen LD, Smolenack SB, Wiebe PH (2000) Population genetic variation of Calanus finmarchicus in Icelandic waters: preliminary evidence of genetic differences between Atlantic and Arctic populations. ICES J Mar Sci 57:1592-1604

Burton RS, Fieldman MV (1982) Population genetics of coastal and estuarine invertebrates: does larval behaviour influence population structure? In: Kennedy ES (ed) Estuarine comparisons. Academic Press, New York, p 537-551

Comes HP, Abbot RJ (2000) Random amplified polymorphic DNA (RAPD) and quantitative trait analyses across a major phylogeographical break in the Mediterranean ragwort Senecio gallicus Vill. (Asteraceae). Mol Ecol 9:61-67

Crisp DJ (1976) The role of pelagic larvae. In: Spencer-Davis $P$ (ed) Perspectives in experimental zoology. Pergamon Press, Oxford, p 145-155

Crisp DJ (1978) Genetic consequences of different reproductive strategies in marine invertebrates. In: Battaglia B, Beardmore JA (eds) Marine organisms: genetics, ecology and evolution. Plenum, New York, p 257-273

Dahlgren TG, Weinberg JR, Halanych KM (2000) Phylogeography of the ocean quahog (Arctica islandica): influences of paleoclimate on genetic diversity and species range. Mar Biol 137:487-495

Daniels SR, Stewart BA, Gibbons MJ (1998) Genetic and morphometric variation in the potamonautid river crab Potamonautes parvispina (Decapoda: Potamonautidae) from 2 Western Cape rivers, South Africa. J Nat Hist 32: 1245-1258

Diaz RJ, Rosenberg R (1995) Marine benthic hypoxia: a review of its ecological effects and the behavioural responses of benthic macrofauna. Oceanogr Mar Biol Annu Rev 33:245-303

Excoffier L (2000) Analysis of population subdivision. In: Balding D, Bishop M, Cannings C (eds) Handbook of statistical genetics. Wiley \& Sons, London, p 271-308

Excoffier L, Smouse PE, Quattro JM (1992) Analysis of molecular variance inferred from metric distances among DNA haplotypes: application to human mitochondrial DNA data. Genetics 131:479-491

Forster GR (1981) A note on the growth of Arctica islandica. J Mar Biol Assoc UK 61:817

Fritz LW (1991) Seasonal condition change, morphometrics, growth and sex ratio of the ocean quahog, Arctica islandica (Linnaeus, 1767) off New Jersey (USA). J Shellfish Res 10:79-88

Gardner JPA, Pande A, Eyles RF, Wear RG (1996) Biochemical genetic variation among populations of the greenshell mussel, Perna canaliculus, from New Zealand: preliminary findings. Biochem Syst Ecol 24:763-774

Grosberg RK, Levitan DR, Cameron BB (1996) Characterization of genetic structure and genealogies using RAPDPCR markers: a random primer for the novice and nervous. In: Ferraris JD, Palumbi SR (eds) Molecular zoology: advances, strategies and protocols. Wiley-Liss, New York, p $67-100$

Hansen TA (1978) Larval dispersal and species longevity in lower Tertiary gastropods. Science 199:885-887

Hartl DL (1980) Principles of population genetics. Sinauer Associates, Sunderland, MA

Hateley JG, Grant A, Taylor SM, Jones MV (1992) Morphological and other evidence on the degree of genetic differentiation between populations of Nereis-diversicolor. J Mar Biol Assoc UK 72:365-381

Havenhand H (1995) Evolutionary ecology of larval types. In: McEdward L (ed) Ecology of marine invertebrate larvae. CRC Press, Boca Raton, FL, p 79-122

Heipel DA, Bishop JDD, Brand AR, Thorpe JP (1998) Population genetic differentiation of the great scallop Pecten maximus in western Britain investigated by randomly amplified polymorphic DNA. Mar Ecol Prog Ser 162: 163-171

Hill AE, Brown J, Fernand L (1996) The western Irish Sea gyre: a retention system for Norway lobster (Nephrops norvegicus)? Oceanol Acta 19:357-368

Hillis DM, Moritz C, Mable BK (1996) Molecular systematics. Sinauer Associates, Sunderland, MA

Jablonski D (1986) Larval ecology and macroevolution in marine invertebrates. Bull Mar Sci 39:565-597

Jackson JBC (1986) Modes of dispersal of clonal benthic invertebrates: consequences for species distribution and genetic structure of local populations. Bull Mar Sci 39: 588-606

Jones DS (1981) Reproductive cycles of the Atlantic surf clam, (Spisula solidissima), and the ocean quahog (Arctica islandica), off New Jersey. J Shellfish Res 1:23-32

Josefson AB, Widbom B (1988) Differential response of benthic macrofauna and meiofauna to hypoxia in the Gullmars-Fjord Basin. Mar Biol 100:31-40

Kennish MJ, Lutz RA (1995) Assessment of the ocean quahog, Arctica islandica (Linnaeus, 1767), in the New-Jersey Fishery. J Shellfish Res 14:45-52

Kennish MJ, Lutz RA, Dobarro JA, Fritz LW (1994) In situ growth rates of the ocean quahog, Arctica islandica (Linnaeus, 1767), in the Middle Atlantic Bight. J Shellfish Res 13:473-478

Kraus MG, Beal BF, Chapman SR, McMartin L (1992) A comparison between growth rates in Arctica islandica (Lin- 
naeus, 1767) between field and laboratory populations. J Shellfish Res 11:289-294

Krzanowski WJ (1993) Principles of multivariate analysis, a user's perspective. Clarendon Press, Oxford

Leppakoski E (1968) Some effects of pollution on the benthic environment of the Gullmarsfjord. Helgol Wiss Meeresunters 17:291-301

Levin LA (1990) A review of methods for labelling and tracking marine invertebrate larvae. Ophelia 32:115-144

Levin LA, Bridges TS (1995) Pattern and diversity in reproduction and development. In: McEdward L (ed) Ecology of marine invertebrate larvae. CRC Press, Boca Raton, FL, p 1-48

Loosanoff VL (1953) Reproductive cycle in Cyprina islandica. Bull Mar Biol Lab (Woods Hole) 104:146-155

Lutz RA, Mann R, Goodsell JG, Castagna M (1982) Larval and early post-larval development of Arctica islandica. J Mar Biol Assoc UK 62:745-769

Lynch M, Milligan B (1994) Analysis of population genetic structure with RAPD markers. Mol Ecol 3:91-99

Mann R (1982) The seasonal cycle of gonadal development in Arctica islandica from southern New England Shelf. Fish Bull 80:315-326

Mann R, Wolf CC (1983) Swimming behaviour of larvae of the ocean quahog Arctica islandica in response to pressure and temperature. Mar Ecol Prog Ser 13:211-218

Mantel N (1967) The detection of disease clustering and a generalised regression approach. Cancer Res 27:209-220

Merrill AS, Ropes JW (1969) The general distribution of the surfclam and ocean quahog. Proc Natl Shellfish Assoc 59: $40-45$

Morgan SG (1995) Life and death in the plankton: larval mortality and adaptation. In: McEdward L (ed) Ecology of marine invertebrate larvae. CRC Press, Boca Raton, FL, p 249-278

Murawski SA, Serchuk FM (1989) Mechanized shellfish harvesting and its management: the offshore clam fishery of the eastern United States. In: Caddy JF (ed) Marine invertebrate fisheries: their assessment and management. Wiley Interscience, New York, p 479-507

Murawski SA, Ropes JW, Serchuk FM (1982) Growth of the ocean quahog, Arctica islandica, in the Middle Atlantic Bight. Fish Bull 80:21-34

Nicol D (1951) Recent species of the Veneriod pelecypod Arctica. J Wash Acad Sci 41:102-106

Nordberg K, Gustafsson M, Krantz AL (2000) Decreasing oxygen concentrations in the Gullmar Fjord, Sweden, as confirmed by benthic foraminifera, and the possible association with NAO. J Mar Syst 23:303-316

Oeschger R (1990) Long-term anaerobiosis in sublittoral marine-invertebrates from the western Baltic Sea-Halicryptus spinulosus (Priapulida), Astarte borealis and Arctica islandica (Bivalvia). Mar Ecol Prog Ser 59:133-143

Palumbi SR (1995) Using genetics as an indirect estimator of larval dispersal. In: McEdward L (ed) Ecology of marine invertebrate larvae. CRC Press, Boca Raton, FL, p 369-412

Palumbi SR (1996) Nucleic acids II: the polymerase chain reaction. In: Hillis DM, Mortiz C, Mable BK (eds) Molecular systematics. Sinauer Associates, Sunderland, MA

Palumbi SR, Metz E (1991) Strong reproductive isolation between closely related tropical sea urchins (genus Echinometra). Mol Biol Evol 8:227-239

Papadopoulou K, Ehaliotis C, Tourna M, Kastanis P, Karydis I, Zervakis G (2002) Genetic relatedness among dioecious Ficus carica L. cultivars by random amplified polymorphic DNA analysis, and evaluation of agronomic and morphological characters. Genetica 114:183-194
Patwary MU, Kenchington EL, Bird CJ, Zouros E (1994) The use of random amplified polymorphic DNA markers in genetic studies of the Sea Scallop Placopecten magellanicus (Gmelin, 1917). J Shellfish Res 13:547-533

Pechenik JA (1987) Environmental influences on larval survival and development. In: Giese AC, Pearse JS (eds) Reproduction of marine invertebrates, Vol 9. Academic Press, New York, p 551-608

Pechenik JA (1999) On the advantages and disadvantages of larval stages in benthic marine invertebrate life cycles. Mar Ecol Prog Ser 177:269-297

Rohner M, Bastrop R, Jurss K (1996) Colonization of Europe by two American genetic types or species of the genus Marenzelleria (Polychaeta: Spionidae). An electrophoretic analysis of allozymes. Mar Biol 127:277-287

Ropes JW (1979) Biology and distribution of surf clams (Spisula solidissima) and ocean quahogs (Arctica islandica) off the northwestern coast of the United States. Proc Northeast Clam Industries: management for the future. University of Massachusetts and Massachusetts Institute of Technology, Sea Grant Program SP-112:47-66

Rosenberg R (1990) Negative oxygen trends in Swedish coastal bottom waters. Mar Pollut Bull 21:335-339

Rousset F (2000) Inference from spatial population genetics. In: Balding D, Bishop M, Cannings C (eds) Handbook of statistical genetics. Wiley \& Sons, London

Rowell TW, Chaisson DR (1983) Distribution and abundance of the ocean quahog (Arctica islandica) and Stimpson's surf clam (Spisula polynyma) resource on the Scotian Shelf. Can Ind Rep Fish Aqua Sci 142:75

Rowell TW, Chaisson DR, Mclane JT (1990) Size and age of sexual maturity and annual gametogenic cycle in the ocean quahog, Arctica islandica (Linnaeus, 1767), from coastal waters in Nova Scotia, Canada. J Shellfish Res 9 195-203

Rumohr H, Krost P (1991) Experimental-evidence of damage to benthos by bottom trawling with special reference to Arctica Islandica. Meer Rep Mar Res 33:340-345

Ruzzante DE, Taggart CT, Cook D (1998) A nuclear DNA basis for shelf- and bank-scale population structure in northwest Atlantic cod (Gadus morhua): Labrador to Georges Bank. Mol Ecol 7:1663-1680

Ruzzante DE, Taggart CT, Cook D (1999) A review of the evidence for genetic structure of cod (Gadus morhua) populations in the NW Atlantic and population affinities of larval cod off Newfoundland and the Gulf of St. Lawrence. Fish Res 43:79-97

Scheltema RS (1989) Planktonic and non-planktonic development among prosobranch gastropods and its relationship to the geographic range of the species. In: Ryland JS, Tyler PA (eds) Reproduction, genetics and distribution of marine organisms. Twenty-third European Marine Biology Symposium 1988. Olsen \& Olsen, Fredensborg, p 183-188

Schneider S, Roessli D, Excoffier L (2000) Arlequin ver. 2.000: a tool for population genetic data analysis. Genetics and Biometry Laboratory, University of Geneva

Schwaninger HR (1999) Population structure of the widely dispersing marine bryozoan Membranipora membranacea (Cheilostomata): implications for population history, biogeography, and taxonomy. Mar Biol 135:411-423

Shanks AL (1995) Mechanisms of cross-shelf dispersal of larval invertebrates. In: McEdward L (ed) Ecology of marine invertebrate larvae. CRC Press, Boca Raton, FL, p 323-368

Slatkin M (1985) Gene flow in natural populations. Annu Rev Ecol Syst 16:393-430 
Sokal RR, Rohlf JF (2000) Biometry. WH Freeman \& Co New York

Stepien CA, Dillon AK, Patterson AK (2000) Population genetics, phylogeography and systematics of the thornyhead rockfishes (Sebastolobus) along the deep continental slopes of the North Pacific ocean. Can J Fish Aquat Sci 57: 1701-1717

Stewart CN, Excoffier L (1996) Assessing population genetic structure and variability with RAPD data: application to Vaccinum macrocarpon (American Cranberry). J Evol Biol 9:153-171

Svendsen E, Etre SA, Mork M (1991) Features of the northern North Sea circulation. Cont Shelf Res 11:493-508

Swain DP, Foote CJ (1999) Stocks and chameleons: the use of phenotypic variation in stock identification. Fish Res 43: $113-128$

Swofford DL (2002) PAUP*. Phylogenetic analysis using parsimony ( ${ }^{*}$ and other methods). Version 4.10. Sinauer Associates, Sunderland, MA

Tebble N (1966) British bivalve seashells. The British Museum (Natural History), London

Theede H, Ponat A, Hiroki K, Schlieper C (1969) Studies on the resistance of marine bottom invertebrates to oxygen deficiency and hydrogen sulphide. Mar Biol 2:325-337

Thompson I, Jones DS, Ropes JW (1980a) Advanced age for sexual maturity in the ocean quahog Arctica islandica (Mollusca: Bivalvia). Mar Biol 57:35-39

Thompson I, Jones DS, Dreibelbis D (1980b) Annual internal growth banding and life history of the ocean quahog, Arctica islandica (Mollusca: Bivalvia). Mar Biol 57:25-34

Thorarinsdottir GG (2000) Annual gametogenic cycle in ocean quahog, Arctica islandica from north-western Iceland. J Mar Biol Assoc UK 80:661-666

Thorarinsdottir GG, Steingrimsson SA (2000) Size and age at sexual maturity and sex ratio in ocean quahog, Arctica

Editorial responsibility: Otto Kinne (Editor),

Oldendorf/Luhe, Germany islandica (Linnaeus, 1767), off northwest Iceland. J Shellfish Res 19:943-947

Turrell WR (1992a) New hypotheses concerning the circulation of the northern North Sea and its relation to North Sea fish stock recruitment. ICES J Mar Sci 49:107-123

Turrell WR (1992b) The eastern Shetland Atlantic inflow. In: Dickson RR (ed) Hydrobiological variability in the ICES area, 1980-1989. ICES Mar Sci Symp 195:127-143

Vainola R, Hvilsom MM (1991) Genetic-divergence and a hybrid zone between Baltic and North-Sea Mytilus populations (Mytilidae, Mollusca). Biol J Linn Soc 43: $127-148$

Van Oppen MJH, Olsen JL, Stam WT (1995) Genetic variation within and among North Atlantic and Baltic populations of the benthic alga Phycodrys rubens (Rhodophyta). Eur J Phycol 30:251-260

Wilde de PAWJ, Berghuis EM, Kok A (1986) Biomass and activity of benthic fauna on the Fladen Ground (northern North Sea). Neth J Sea Res 20:313-323

Witbaard R (1996) Growth variations in Arctica islandica L. (Mollusca): a reflection of hydrography-related food supply. ICES J Mar Sci 53:981-987

Witbaard R (1997) Tree of the sea. PhD thesis, University of Groningen

Witbaard R, Duineveld GCA (1990) Shell-growth of the bivalve Arctica islandica (L.), and its possible use for evaluating the status of the benthos in the subtidal North Sea. Bacteria 54:63-74

Witbaard R, Franken R, Visser B (1997) Growth of juvenile Arctica islandica under experimental conditions. Helgol Meeresunters 51:417-431

Witbaard R, Duineveld GCA, Wilde de PAWJ (1999) Geographical differences in the growth rates of Arctica islandica (Mollusca: Bivalvia) from the North Sea and adjacent waters. J Mar Biol Assoc UK 79:907-915

Submitted: July 5, 2002; Accepted: December 10, 2002 Proofs received from author(s): May 5, 2003 